
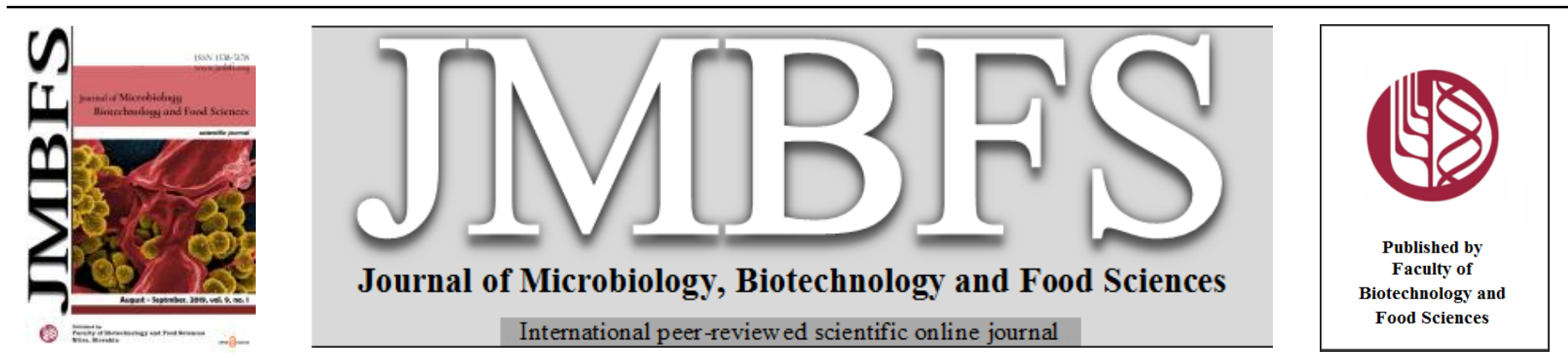

\title{
EFFECT OF DIFFERENT FOOD STRESS CONDITIONS ON THE VIABILITY OF ENCAPSULATED Lactobacillus plantarum AND Lactobacillus casei ISOLATED FROM KLILA (AN ALGERIAN TRADITIONAL FERMENTED CHEESE)
}

\section{Samiya Amira ${ }^{1}$, Mohamed Sifour $*^{1}$, Houria Ouled-Haddar ${ }^{1}$, Sawsen Hadef ${ }^{2}$, Tarek Khennouf ${ }^{3}$, Gianluigi Mauriello ${ }^{4}$, Diamante Maresca $^{4}$}

Address(es):

${ }^{1}$ Laboratory of Molecular Toxicology, Faculty of Nature and Life Sciences, University of Mohamed Seddik Benyahia, Jijel 18000, Algeria.

${ }^{2}$ Department of Biological Sciences, University Center of Abdelhafid Boussouf, Mila, Algeria.

${ }^{3}$ Laboratory of Biotechnology Environment and Health, Faculty of Nature and Life Sciences, University of Mohamed Seddik Benyahia, Jijel 18000, Algeria.

${ }^{4}$ University of Naples Federico II, Department of Agriculture, , via Universita 100, 80055 Portici, NA, Italy.

*Corresponding author: sifourm@yahoo.fr

doi: 10.15414/jmbfs.2019.9.1.38-43

\section{ARTICLE INFO}

Received 13. 11. 2018

Revised 25. 2. 2019

Accepted 4. 3. 2019

Published 1. 8. 2019

$\underline{\text { Regular article }}$ open 2 access

\section{ABSTRACT}

Klila is one of a variety of Algerian traditional cheeses. The present work aimed to study the viability of two lactobacilli: Lactobacillus plantarum and Lactobacillus casei isolated from Klila and immobilized by extrusion in $2 \%$ sodium alginate under different stress conditions (different $\mathrm{NaCl}$ concentrations, sugar stress, different $\mathrm{pH}$ values and simulated gastrointestinal conditions) during storage at $4^{\circ} \mathrm{C}$.

Results showed that viability of encapsulated cells was enhanced at high salt concentration; at $9 \%$, viability of free $\mathrm{Lb}$. casei cells decreased by $9 \mathrm{Log}$ CFU/ml 14 days, and by only $0.2 \mathrm{Log}$ CFU/ml for encapsulated cells. Encapsulated Lb. plantarum resisted up to 28 days while viability of free cells decreased by $9 \mathrm{Log} \mathrm{CFU} / \mathrm{ml}$ in the $7^{\text {th }}$ day at $9 \%$.

$\mathrm{pH} 2$ showed the lowest viability which is decreased as the time of storage increased. After 14 days of storage, Lb. casei free cells decreased by $9 \mathrm{Log}$ CFU/ml, encapsulated ones by only $2.8 \mathrm{Log}$ CFU/ml, Lb. plantarum free cells by 9 Log CFU/ml and by $2.6 \mathrm{Log}$ $\mathrm{CFU} / \mathrm{ml}$ for encapsulated cells. Exposure to simulated gastrointestinal conditions showed that Lb. casei resisted such conditions compared to non-encapsulated cells which was not the case with $\mathrm{Lb}$. plantarum.

Storage in a commercial strawberry beverage showed that free cells did not resist more than the $7^{\text {th }}$ day while coated cells resisted till the $14^{\text {th }}$ day. We conclude that encapsulation enhance the viability of bacteria in harsh conditions.

Keywords: Klila, lactobacilli, encapsulated, extrusion, viability, stress conditions

\section{INTRODUCTION}

Probiotics are live microorganisms which when administered in adequate quantities confer beneficial effects on the health of the host (FAO/WHO, 2002). To be considered as potentially probiotic, microbial cells should be able to stay viable and stable in front of storage conditions, they should also overcome the harsh conditions of the human or animal gastrointestinal tract. Probiotics are able to improve the intestinal microbial balance through various mechanisms (Krasaekoopt et al., 2003; Vasiljevic and Shah, 2008; Vrese and Schrezenmeir, 2008; Bron et al., 2012; Amine et al., 2014), in addition, they possess antimutagenic and anticarcinogenic properties. Even though they are regarded as safe, probiotics should not carry transferable antibiotic resistance genes (Havennar and Huisint't Veld, 1992; Holzapfel and Schillinger, 2002). On the other hand, viability loss of probiotic cells during their storage within a food matrix is a commonly encountered problem (Brinques and Ayub, 2011; Amine et al., 2014). One of the solutions is microencapsulation, known to be suitable for the oral delivery of living probiotic bacteria making it a powerful and a promising food technology (Heidebach et al., 2009; Malmo et al., 2013; Damodharan et al., 2017). It lowers cell loss and consequently increases cell viability, which is usually altered during storage, industrial processing, or throughout the food digestion process, because of the high resistance conferred by the immobilzation (Chavarri et al., 2010; Chen et al., 2017).

Basically, using different cell encapsulation techniques, such as direct gelation, emulsification or complex coacervation, the probiotic bacteria are entrapped into polymeric microbeads. The matrix itself is made of one or more types of biopolymers, commonly used as food additives, all originating from nature, like alginate and carrageenan from algae, starch, arabic gum, soy and pea protein from plants, gellan and xanthan from bacteria and milk, gelatin and whey protein from animal origin. These polymers were reported to be biologically compatible and safe for both bacteria and consumer. (Dong et al., 2013; Bosnea et al., 2014; Wang et al., 2014; Eratte et al., 2015).
Alginate, known to be regarded as safe, bioavailable, biocaompatible and cost effective as well as easily prepared is widely used to immobilize probiotic microorganisms. This anionic polymer is obtained from brown seaweed, and is composed of a succession of 1,4-linked $\beta$-D-mannuronic acid and $\alpha$-L-guluronic acid monomers (Mokarram et al., 2009).

According to FAO/WHO (2001) guidelines, and prior to be used as food added probiotics, the new candidate bacterial strains should be necessarily evaluated for their survival rate in the following conditions: gastrointestinal, processing as well as storage conditions. In addition, lactic acid bacteria are evidently the most important group of bacteria comprising powerful probiotics, as their beneficial role in food, agriculture and medicine is very well documented (Bintsis, 2018).

In the present work, the principal aim is to study the viability of two probiotic lactobacilli strains ( $L b$. plantarum and $L b$. casei) isolated from a traditional Algerian fermented cheese "Klila" immobilized in sodium alginate beads after exposure to different stress conditions (different $\mathrm{NaCl}$ concentrations, strawberry juice, different $\mathrm{pH}$ values and simulated gastrointestinal conditions).

\section{MATERIALS AND METHODS}

Isolation and identification of lactobacilli

After serial dilution of "Klila" in normal saline, and seeding on MRS agar plates, the incubation was performed at $37{ }^{\circ} \mathrm{C}$ for $48 \mathrm{~h}$. Separated colonies were taken and inoculated again on MRS agar till obtaining pure cultures with the same shape, same color, and same size. Morphology, Gram staining, catalase test, growth at various temperatures, and the carbohydrates fermentation test were performed to identify the bacterial isolates (the used carbohydrates were: sucrose, mannose, glucose, galactose, xylose, sorbose, maltose, dextrine, raffinose, starch, glycerol, salicine and adonitol) (Schillinger and Lücke, 1987; Stiles and Holzapfel, 1997). The identification was confirmed by $16 \mathrm{~S}$ rDNA technique. Stock cultures were preserved in MRS broth (CONDA, pronadisa, Madrid, Spain) with glycerol $(30 \%)$ at $-20{ }^{\circ} \mathrm{C}$ and were subcultured twice in MRS broth 
( $\mathrm{pH}$ 6.2) for activation prior to be used. The purity was confirmed by culture on MRS agar and by Gram staining; cultures were incubated at $37^{\circ} \mathrm{C}$ for $48 \mathrm{~h}$.

\section{Encapsulation of bacterial cells}

The described method by Sheu et al. (1993) with some modifications was used. An overnight culture of bacteria on MRS broth was centrifuged for $10 \mathrm{~min}$ at $6,000 \mathrm{rpm}$. The obtained cell pellets were then washed with $10 \mathrm{ml}$ of normal saline $(0.9 \%)$ and were resuspended in the same volume of distilled water. From a stock culture, fresh cells were prepared for each one of the experiments carried out in duplicate $(n=2)$. Cell concentration was adjusted to approxiametely $\sim 10^{10}$ $10^{11} \mathrm{CFU} / \mathrm{ml}$. This bacterial suspension was mixed with autoclaved sodium alginate (SIGMA, Milan, Italy) solution at $2 \%$ then let droplet through a syringe of $2.5 \mathrm{ml}$ in a cooled solution of $\mathrm{CaCl}_{2}$ under slight agitation.

The amount of beads corresponding to $1 \mathrm{ml}$ of the bacterial suspension was quantified, the cell suspension was mixed with a solution of $2 \%(\mathrm{w} / \mathrm{v})$ sodium alginate, and the number of beads corresponding to $1 \mathrm{ml}$ was counted. This procedure was repeated 5 times. The average obtained number was 50 beads per $1 \mathrm{ml}$.

\section{Tolerance to acid pH}

One $\mathrm{ml}$ of the bacterial suspension mentioned above (free cells) and 50 beads of encapsulated bacteria (immobilized cells) were added to $9 \mathrm{ml}$ of normal saline $(0.9 \% \mathrm{NaCl})$ separately at three $\mathrm{pH}$ values, 2,4 and 7 according to the method described by Bosnea et al. (2014). The incubation was carried out at $4{ }^{\circ} \mathrm{C}$ for $3 \mathrm{~h}$, 7 and 14 days for evaluation of the applied stress and $1 \mathrm{ml}$ of the previous solutions was transferred to $9 \mathrm{ml}$ of phosphate buffered saline PBS and after serial dilutions viable cell count was determined on MRS agar. This experiment was carried out in duplicate.

\section{Tolerance to $\mathrm{NaCl}$}

Three saline solutions with different salt concentrations were used $(3 \%, 6 \%$ and $9 \%$ ), and the same procedure used for the $\mathrm{pH}$ stress was followed. The mixture was incubated at $4{ }^{\circ} \mathrm{C}$ for $3 \mathrm{~h}, 7,14,21$ and 28 days (Bosnea et al., 2014). Cell count was determined as previously described.

\section{Storage in strawberry juice}

To evaluate the effect of strawberry beverage composition on the viability of both strains, one $\mathrm{ml}$ of free and encapsulated cells was introduced separately in tubes containing $9 \mathrm{ml}$ of a commercial strawberry beverage (TOUDJA, Bejaia, Algeria). The tubes were stored at $4{ }^{\circ} \mathrm{C}$, and viable count on MRS agar was evaluated at $0,3 \mathrm{~h}, 7$ and 14 days. The initial cell number in the beverage was approximately $2 \times 10^{10} \mathrm{CFU} / \mathrm{ml}$ for both strains (Nualkaekul et al., 2013).

\section{Viability under simulated gastrointestinal (GI) conditions}

The assay was performed according to Vizoso $\boldsymbol{e t}$ al. (2006). Viable cell counts were monitored during initial exposure to gastrointestinal (GI) conditions, after 2 hours to assess the gastric transit tolerance, and after $4 \mathrm{~h}$ to evaluate the intestinal transit tolerance. The simulated gastric juice (SGJ) was prepared using $0.3 \%$ (w/v) pepsin (SIGMA, Milan, Italy), $0.5 \%$ (w/v) $\mathrm{NaCl}, 0.22 \%$ (w/v) KCl, $0.12 \%$ (w/v) $\mathrm{NaHCO}_{3}$ and $0.022 \%(\mathrm{w} / \mathrm{v}) \mathrm{CaCl}_{2}$; the simulated gastric juice was acidified with $\mathrm{HCl}(0.1 \mathrm{M})$ to $\mathrm{pH} 2.5$. Simulated intestinal juice (SIJ) was prepared with $0.1 \%$ (w/v) pancreatin and $0.128 \%$ (w/v) $\mathrm{NaCl}, 0.023 \%$ (w/v) $\mathrm{KCl}, 0.64 \%$ (w/v) $\mathrm{NaHCO}_{3}, 0.5 \%$ (w/v) bile salts (SIGMA, Mian, Italy), $\mathrm{pH}$ was adjusted to 7.0 Both solutions were filtered using $0.22 \mu \mathrm{m}$ membranes filters. Free and encapsulated $L b$. plantarum and Lb.casei were exposed to simulated GI conditions and their viability was calculated for different times $(0,2$ and 4$) \mathrm{hrs}$.

\section{Data analysis}

Analysis was carried out in duplicate; MATLAB version 2008 was used for graphic performance. The data were presented as mean \pm standard deviation (SD) values.

\section{RESULTS AND DISCUSSION}

A total of ten (10) Gram-positive, rod-shaped, catalase-negative, ADH-negative, either homofermentative or heterofermentative, able to grow at $45{ }^{\circ} \mathrm{C}$ and unable to grow at $10{ }^{\circ} \mathrm{C}$, belonged to the Lactobacillus genus (Xanthopoulos et al., 2000). Molecular identification revealed that the two strains belonged to the species Lb. plantarum (Accession number: MH342626) and Lb. casei (Accession number: KY764324).

\section{Tolerance of free and encapsulated bacterial cells to acidic $\mathrm{pH}$ stress}

The effect of $\mathrm{pH}$ on the viability of free and encapsulated bacteria was tested at different times of incubation and at three different $\mathrm{pH}$ values (2, 4 and 7). Results are presented in figures $1(\mathrm{a}, \mathrm{b}, \mathrm{c})$ and figure $2(\mathrm{a}, \mathrm{b}, \mathrm{c})$ for $L b$. case $i$ and $L b$. plantarum, respectively, they showed that the lowest viability was recorded at $\mathrm{pH}$ 2 and it decreased as the time of storage increased. For example, the number of Lb. case $i$ free cells was reduced by $8 \mathrm{Log}$ CFU/ml after 7 days and by 9 Log $\mathrm{CFU} / \mathrm{ml}$ after 14 days, however, encapsulated ones were reduced only by $2 \mathrm{Log}$ $\mathrm{CFU} / \mathrm{ml}$ after 7 days and by $2.8 \mathrm{Log} \mathrm{CFU} / \mathrm{ml}$ after 14 days. For Lb. plantarum, the cell number decreased by $6.9 \mathrm{Log} \mathrm{CFU} / \mathrm{ml}$ after 7 days and by $9 \mathrm{Log} \mathrm{CFU} / \mathrm{ml}$ after 14 days for free cells and by $2.3 \mathrm{Log}$ CFU/ml and 2.6 Log CFU/ml after 7 and 14 days, respectively for encapsulated cells. The optimal $\mathrm{pH}$ for storage for both isolates and in both cases (free or encapsulated) was 7. The study of Bosnea et al. (2014) reported similar results, since at low $\mathrm{pH}$ values; the viability of free cells decreased significantly, however, encapsulated ones showed a higher survival rate suggesting that sodium alginate microenvironment is offering to cells an acid resistance feature. In contrast, and after $3 \mathrm{~h}$ of incubation at $4{ }^{\circ} \mathrm{C}$, no effect was observed on the viability of both free and encapsulated forms, at $\mathrm{pH}$ 4.0 and $\mathrm{pH}$ 7.0. In a report of Krasaekoopt et al. (2006), microencapsulated $L b$. acidophilus and $\mathrm{Lb}$. casei in sodium alginate and chitosan beads were added to yoghurt at $\mathrm{pH} 4.7$ and stored at $4{ }^{\circ} \mathrm{C}$. Viability increased by one cycle Log compared to free cells in the cited conditions.

According to Bosnea et al. (2014), the restored viability of bacterial cells at low $\mathrm{pH}$ environments, is attributed to the presence of membrane proton pumps or proton/cation exchange systems, their role is to maintain the cytoplasm $\mathrm{pH}$ near neutrality by controlling the influx of protons. In highly acidic $\mathrm{pH}$ conditions $\left(\mathrm{H}^{+}\right.$ concentration is very high), cells will be disrupted and will consequently lose their viability, this is actually due to the intracellular acidification resulting from the drastic decrease in $\mathrm{pH}$ gradient (the difference between the intracellular and the extracellular $\mathrm{pH}$ ), caused by the dysfunction of the $\mathrm{pH}$ regulatory pumps. Alginate microencapsulation is providing an additional physical defense mechanism to the probiotic cells through a barrier effect.
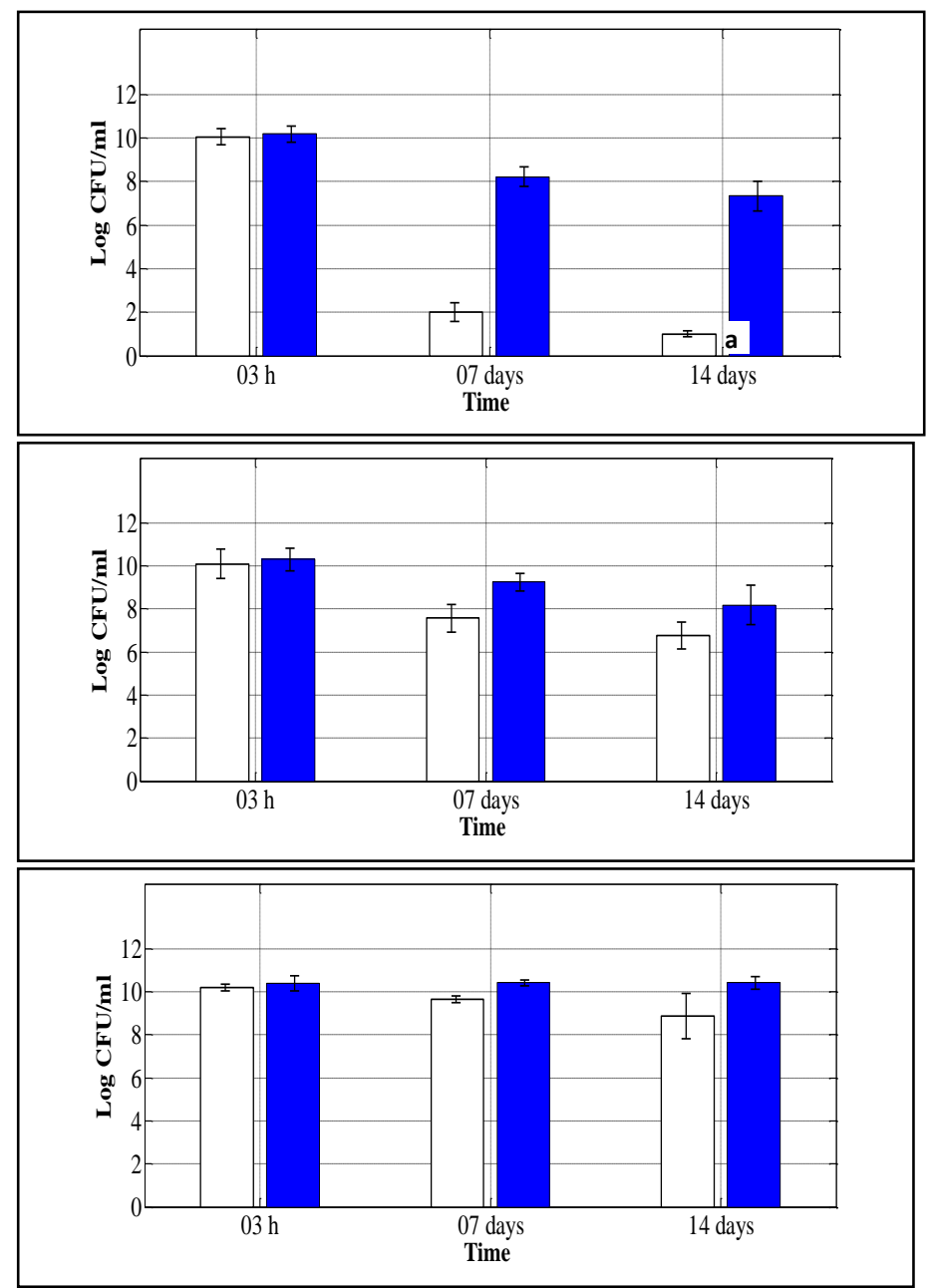

Figure 1 Viability of free (uncolored) and encapsulated (colored) $\mathrm{Lb}$. casei at different $\mathrm{pH}$ values (a: $\mathrm{pH}=2, \mathrm{~b}: \mathrm{pH}=4, \mathrm{c}: \mathrm{pH}=7$ ) after their storage at $4{ }^{\circ} \mathrm{C}$ for 3 h, 07 and 14 days. 

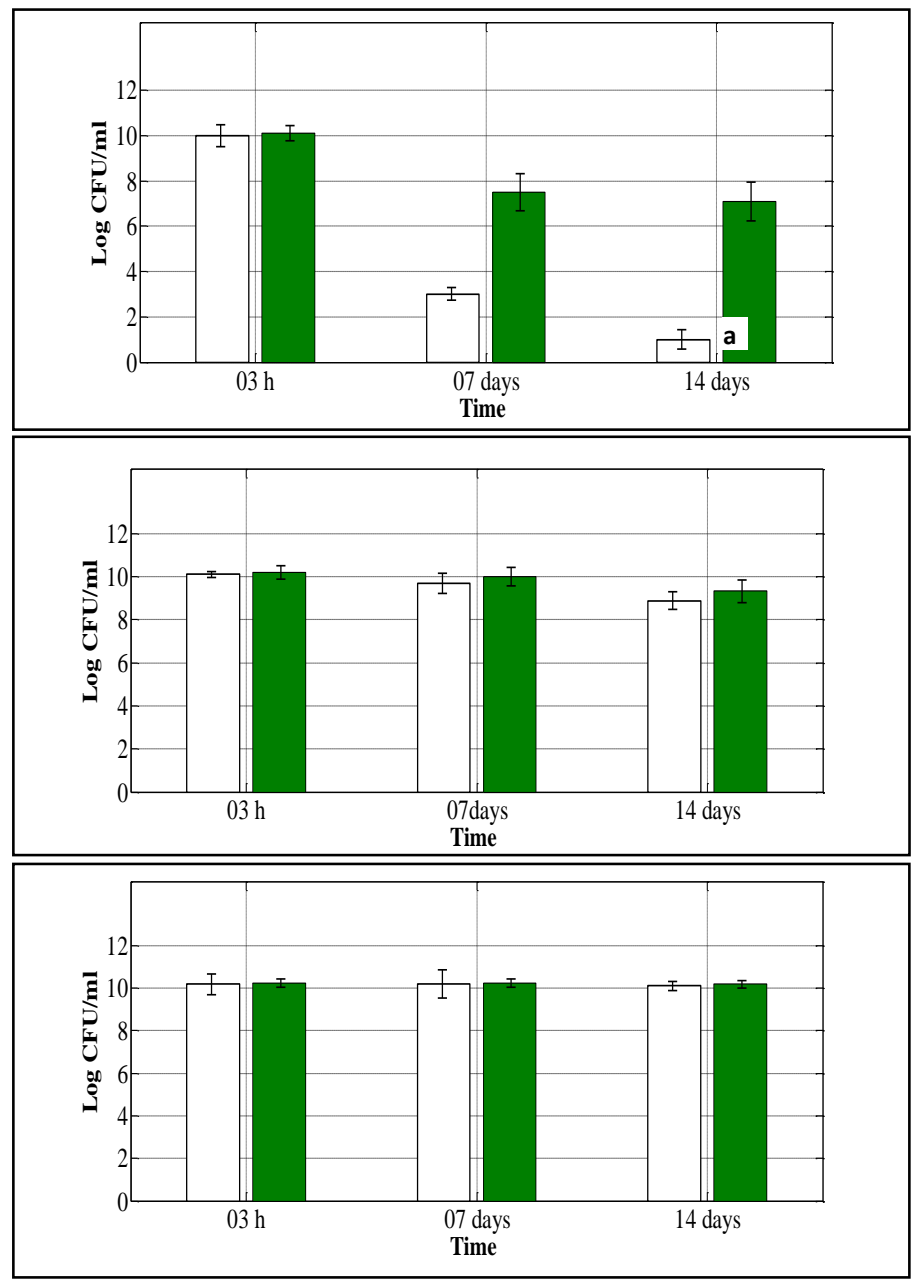

Figure 2 Viability of free (uncolored) and encapsulated (colored) Lb. plantarum at different $\mathrm{pH}$ values (a: $\mathrm{pH}=2, \mathrm{~b}: \mathrm{pH}=4, \mathrm{c}: \mathrm{pH}=7$ ) after their storage at $4{ }^{\circ} \mathrm{C}$ for, $3 \mathrm{~h}, 07$ and 14 days.

\section{Tolerance to $\mathrm{NaCl}$}

The effect of different salt $(\mathrm{NaCl})$ concentrations on the survival of free and encapsulated cells are presented in figure $3(\mathrm{a}, \mathrm{b}, \mathrm{c})$ for $\mathrm{Lb}$. case $i$ and in figure $4(\mathrm{a}, \mathrm{b}, \mathrm{c})$ for $L b$. plantarum.

As clearly shown in the results, the number of encapsulated viable cells was higher than that of free ones at all salt concentrations, it remained unchangeable. Moreover, viability was better at the concentration of 3\% compared to the other concentrations (6\% and $9 \%$ ) for $L b$. casei free cells, where at $3 \%$ it was reduced by $1.7 \mathrm{Log}$ CFU/ml after 28 days of storage and by $4 \mathrm{Log}$ CFU/ml and $9 \mathrm{Log}$ $\mathrm{CFU} / \mathrm{ml}$ after 14 and 28 days, respectively. At $6 \%$, it was reduced by $8.06 \mathrm{Log}$ after 21 days and 9.12 cycles after 28 days and at $9 \%$, it was reduced by $3.6 \mathrm{Log}$ $\mathrm{CFU} / \mathrm{ml}$ and $9 \mathrm{Log} \mathrm{CFU} / \mathrm{ml}$ after 7 and 14 days, respectively. However, $L b$. plantarum free cells were able to resist both $3 \%$ and $6 \% \mathrm{NaCl}$, but at $9 \%$, viability was reduced by $9 \mathrm{Log} \mathrm{CFU} / \mathrm{ml}$ after 14 days of storage at $4{ }^{\circ} \mathrm{C}$. However, encapsulated cells for both isolates resisted all salt concentrations. These results indicated that these bacteria resist harsh conditions of osmolarity, and showed that sodium alginate gives more protection to bacterial cells to resist such conditions of stress. In addition, the concentration of 3\% gave the highest resistance and viability, but it decreased by the increase of salt concentration. Our results agree with those of Gomes et al. (1998) where they reported that the number of $L b$. acidophilus decreased by the increase of salt concentration above 3.0\%. Furthermore, in a study of Cruz et al. (2015), when free Lb. acidophilus cells were exposed to $6 \% \mathrm{NaCl}$, viability decreased and by consequence, the microorganisms become less resistant to osmotic stress. The observed decline in the survival and resistance during storage could be atributed to the reduction in water activity and to the increase in osmolarity (Jorgensen $\boldsymbol{e t}$ al., 1994).

Salts is usually added to foods as a taste enhancer or to prevent spoilage, therefore, at higher levels, the $\mathrm{NaCl}$ content could negatively influence viability of the probiotic cells. However, little is known on the mechanism by which microencapsulated probiotics resist to high salt concentrations found in cheese and other salted foods (Bosnea et al., 2014).
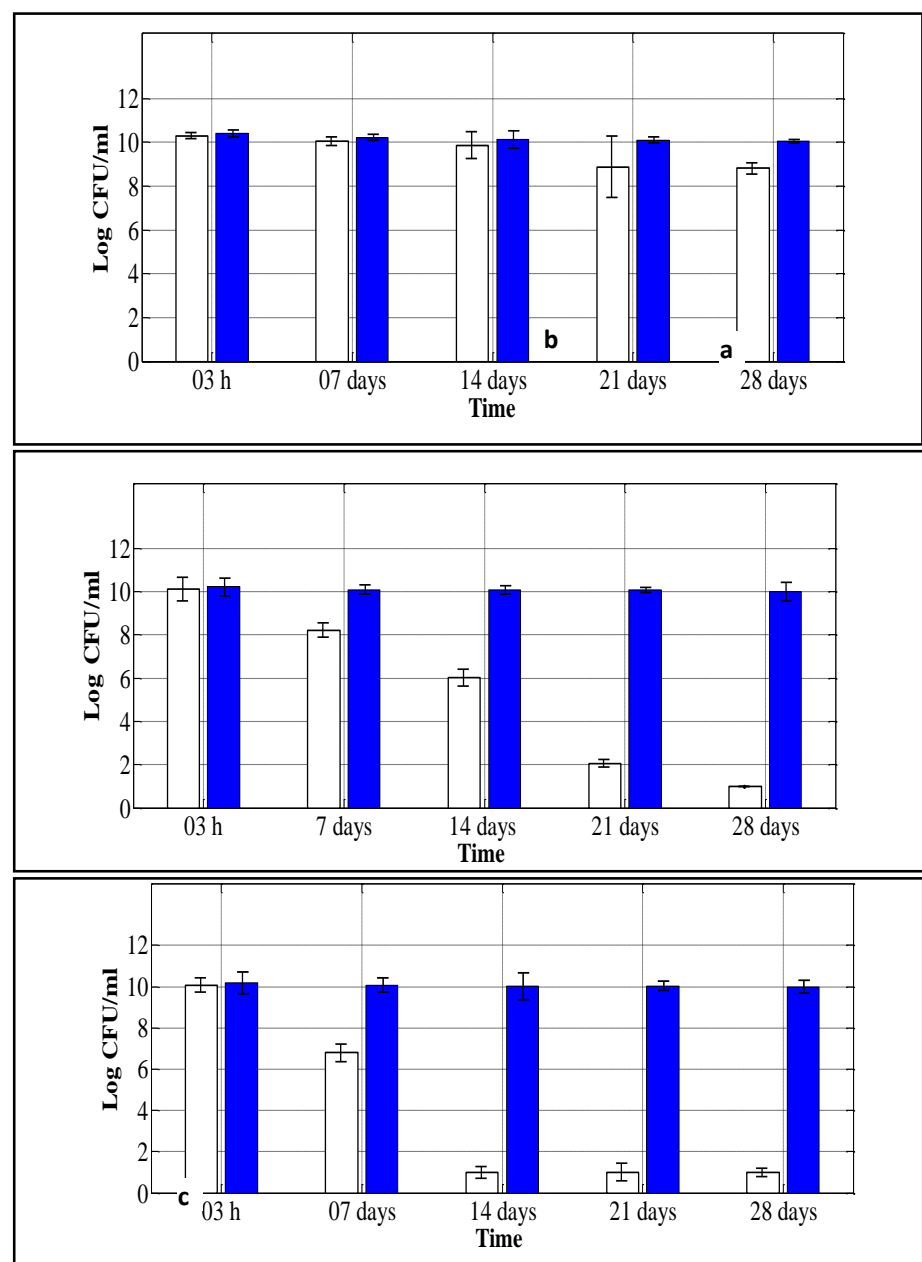

Figure 3 Viability of free (uncolored) and encapsulated (colored) Lb. casei at different $\mathrm{NaCl}$ concentrations (a: $\mathrm{NaCl}=3 \%, b: \mathrm{NaCl}=6 \%, c: \mathrm{NaCl}=9 \%$ ) after their storage at $4{ }^{\circ} \mathrm{C}$ for, $3 \mathrm{~h}, 07,14,21$ and 28 days.

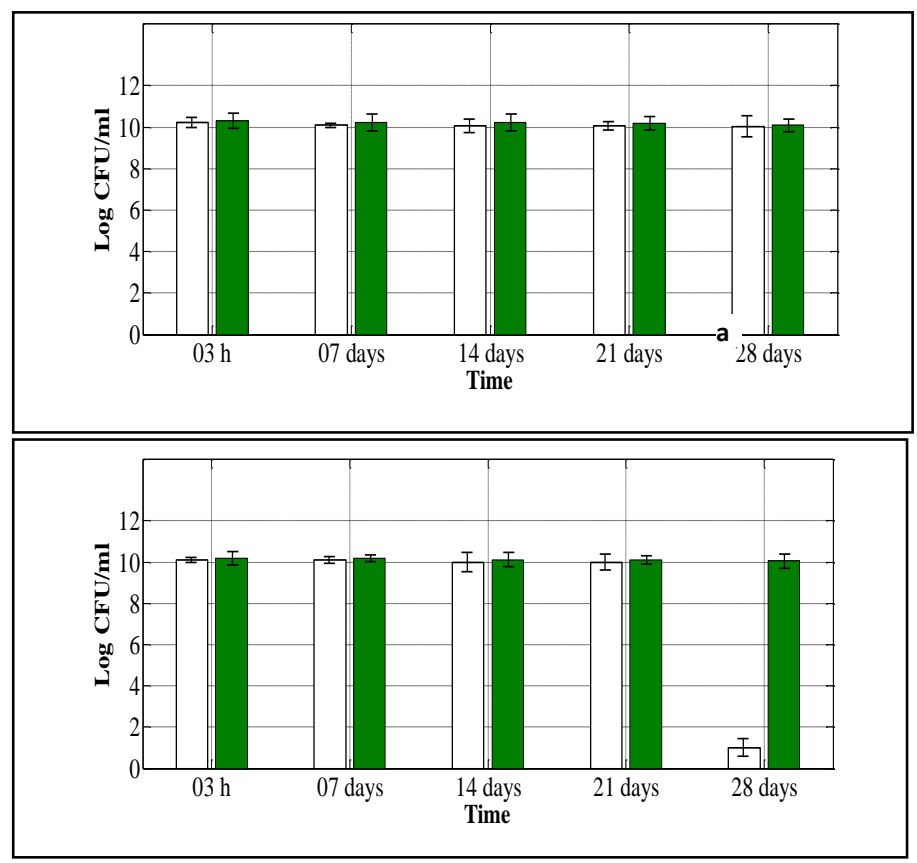




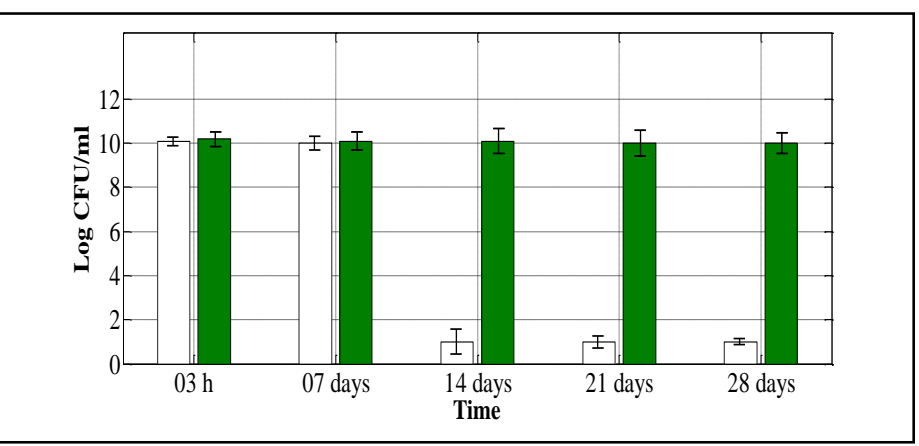

Figure 4 Viability of free (uncolored) and encapsulated (colored) Lb. plantarum at different $\mathrm{NaCl}$ concentrations (a: $\mathrm{NaCl}=3 \%, b: \mathrm{NaCl}=6 \%, \mathrm{c}: \mathrm{NaCl}=9 \%$ ) after their storage at $4{ }^{\circ} \mathrm{C}$ for, $3 \mathrm{~h}, 07,14,21$ and 28 days.

\section{Storage in strawberry juice}

The survival of probiotics embedded in the food matrix could be affected during food processing and storage because they are exposed to several stress conditions namely osmotic stress, high temperature, acidic conditions...etc. For example, the presence of high sugar levels in sweetened foods affects their survival due to the high osmotic conditions (De Prisco et al., 2015).

In the present work, the survival of free and microencapsulated cells in strawberry juice was evaluated. A decrease in viability was observed with time for free cells only, however, the number of encapsulated cells remained unchanged, as shown in figure $5 \mathrm{a}$ for $\mathrm{Lb}$. case $i$ and figure $5 \mathrm{~b}$ for $\mathrm{Lb}$. plantarum, this means that encapsulation in sodium alginate enhanced the viability of bacteria in sugar stress.

The number of $L b$. casei free cells was reduced by $1.9 \mathrm{Log} C \mathrm{FU} / \mathrm{ml}$, and $9 \mathrm{Log}$ $\mathrm{CFU} / \mathrm{ml}$ after 7 and 14 days, respectively, whereas that of encapsulated cells decreased only by $0.2 \mathrm{Log}$ CFU/ml after 14 days. For $L b$. plantarum, viability of free cells decreased after 14 days to reach only $1 \mathrm{Log}$ CFU/ml after 14 days, while for encapsulated cells it was reduced by $0.2 \mathrm{Log}$ CFU/ml after 14 days. The study of De Presco et al. (2015) conducted with apricot jam as a high osmotic pressure food, revealed a significant decline in the survival of free cells compared to microencapsulated ones both subjected to osmotic stress for three hours. The cell number was reduced by about 2 Log cycles for free cells and by about $0.67 \mathrm{Log}$ cycle for microencapsulated ones.

Our result is in agreement with the findings of Nualkaekul $\boldsymbol{e t}$ al. (2013), the researchers compared the survival of Lb. plantarum and Bifidobacterium longum in alginate or pectin beads during storage in pomegranate and cranberry juices. They found that the survival of the cells was improved considerably after being entrapped within both matrices. However, free cells of the two strains died after one week of storage in caranberry juice. Furthermore, free cells of $L b$. plantarum died after 4 weeks and those of $B$. longum after 1 week of storage in pomegranate juice.

During storage, the cell viability decrease for free cells indicated that probiotic cells were highly influenced by the juice composition. In a similar report, Vinderola et al. (2002) indicated that the reduced viability in fruit juices may be prinicipally caused by the presence of some inhibitory food additives such as colorings and aoma. In another study, it was shown that the acidic $\mathrm{pH}$ of fruit juices ranging from 2.5 and 3.7 with benzoic and lactonic acids may reduce viability of probiotics too (Sheehan et al., 2007).

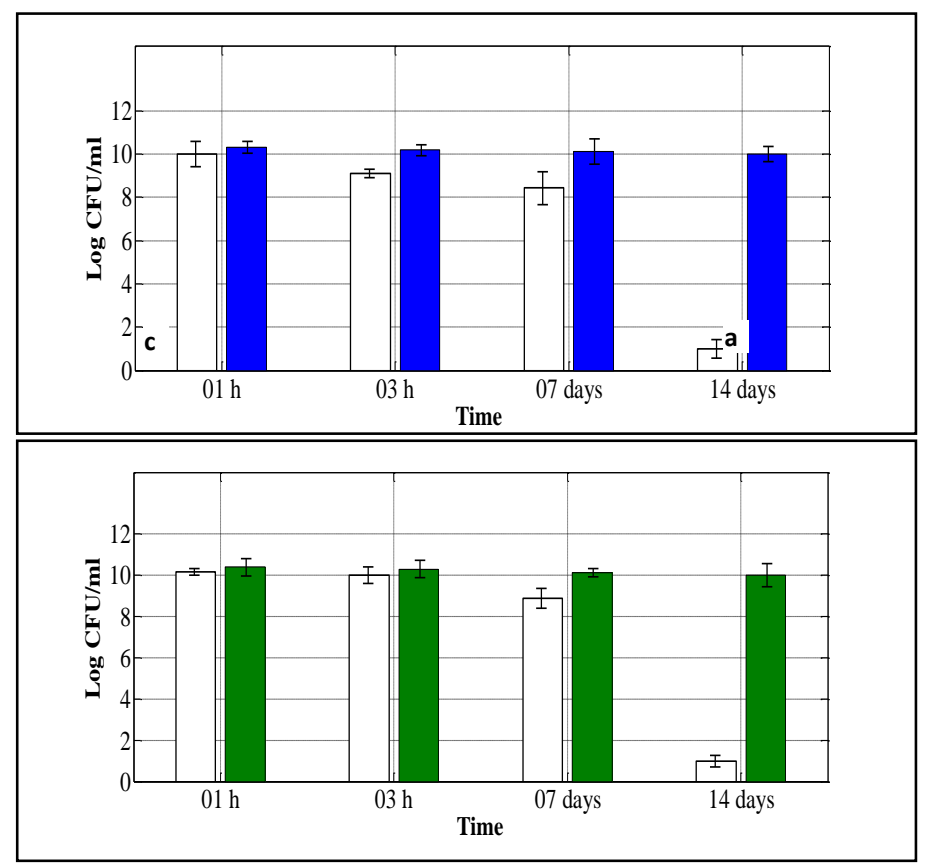

Figure 5 Viability of free (uncolored) and encapsulated (colored) Lb. casei (a) and Lb. plantarum (b) after its storage in fruit juice at $4{ }^{\circ} \mathrm{C}$

\section{Viability under simulated GI conditions}

This test was performed to evaluate the capacity of the probiotics to overcome the stomachal barrier, for this, free and microencapsulated cells were incubated in simulated gastric juice (SGJ), their respective counts were determined. The initial number of viable free cells (approximatly $10.2 \mathrm{Log} \mathrm{CFU} / \mathrm{ml}$ ) decreased to 8. and to $8.3 \mathrm{Log} \mathrm{CFU} / \mathrm{ml}$ for $\mathrm{Lb}$. casei and $\mathrm{Lb}$. plantarum, respectively following $2 \mathrm{~h}$ exposure to SGJ (figures $6 \mathrm{a}$ and $6 \mathrm{~b}$ ).

These results suggested that free and encapsulated $L b$. plantarum and $L$ b. casei cells showed a slight decrease in the number of cells in the acidic environment $(\mathrm{pH} 2.0)$. After 4 hours of incubation in simulated intestinal conditions, $L b$. plantarum showed the same results for both free and encapsulated cells with a decrease of $2.1 \mathrm{Log}$ CFU $/ \mathrm{ml}$. For $\mathrm{Lb}$. casei, encapsulated cells were reduced in number by also $2.2 \mathrm{Log} \mathrm{CFU} / \mathrm{ml}$ however, free cells viability was decrease by 7 Log CFU/ml.

In the study of Dimitrellou et al. (2016), aiming to evaluate the survival of spray-dried microencapsulated Lb. casei ATCC 393 cells exposed to simulated gastrointestinal conditions, the researchers reported a higher survival rate of the entrapped cells compared to free ones, both were subjected to simulated gastric juice and bile salts, in this case, a continuous loss in $\mathrm{Lb}$. casei viability was observed for free cells after exposure to simulated gastric conditions, the viable cell counts dropped by $4.03 \mathrm{Log}$ CFU/g at $\mathrm{pH} 2.0$. Similar findings were also reported by other researchers working on the same species, indeed, free $\mathrm{Lb}$. case ATCC 393 cells showed a decreased survival rates at low pH values (Sidira $\boldsymbol{e t}$ al., 2010; Li et al., 2011; Xu et al., 2016). In addition, spray-drying microencapsulation of $L b$. plantarum provided an efficient protective effect facing bile salts solutions when compared to freeze-drying, this was highlighted by Rajam et al. (2012). Moreover, Mandal et al. (2006) reported also an improved viability of $L b$. casei NCDC-298 cells after being exposed to $1 \%$ and $2 \%$ bile salts for $12 \mathrm{~h}$, this improvement is resulting from alginate encapsulation, and it was proportional to the polymer concentration. In the same context, the study of Brinques and Ayub (2011), using Lb. plantarum BL01, reported that incubation in SG medium showed no change in cell viability compared to free cells, in other words, viability of both free and immobilized cells was deeply affected by the incubation conditions, excluding the protective effect of the polymeric matrix. Other researchers failed to protect probiotic cells through immobilization too, this is the case of Sultana et al. (2000), and Gbassi et al. (2009), who reported a lower protective effect on probiotics at $\mathrm{pH} 2.0$ in the former or a total loss of viability of microencapsulated $L b$. plantarum in the later. Moreover, Michida et al. (2006) found that $L b$. plantarum cells tolerated pefectly the SIJ conditions even at the "free" status.

Other authors suggested that the release of bacteria from their encapsulating material may be due to factors related to bacterial cells including biomass distribution inside the bead, cell density as well as biomass distribution near the surface of the beads. Furthermore, interactions between bacterial cells and the polymers are not to be excluded, since they affect the cell release rate (Klinkenberg et al., 2001; Anal and Singh, 2007). 

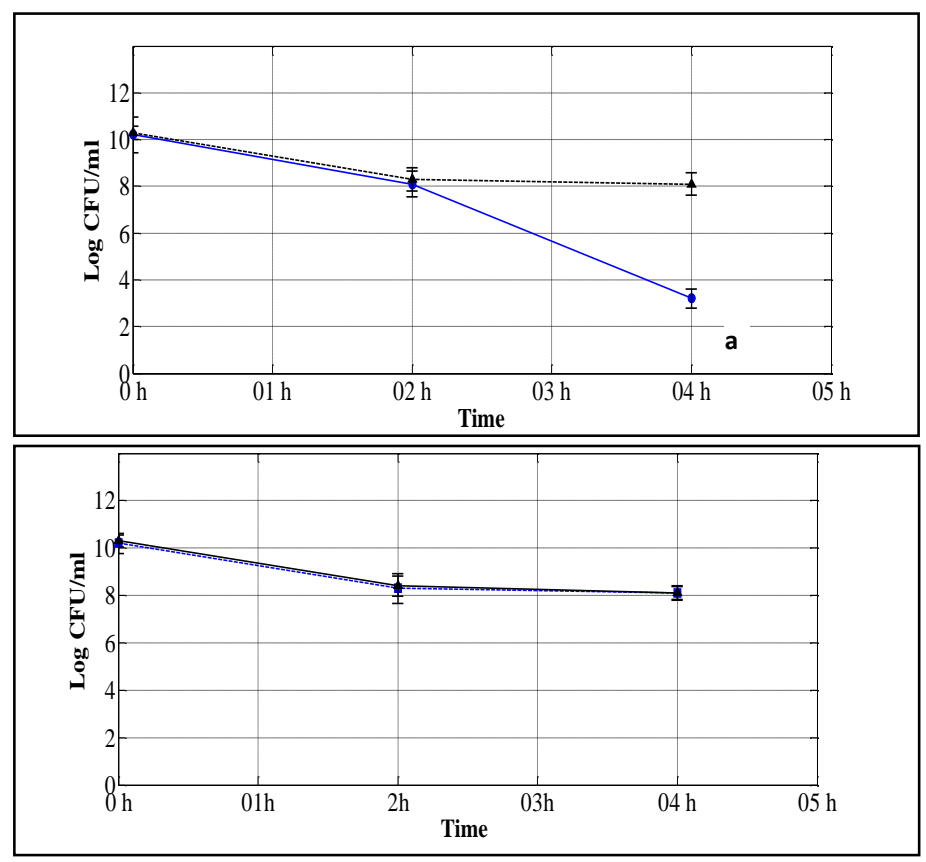

Figure 6 Viability of free (blue line) and encapsulated (black line) Lb. casei (a) and $L b$. plantarum (b) under simulated gastrointestinal (SGI) conditions

\section{CONCLUSION}

This study presented the encapsulation of probiotic bacteria $L b$. casei and $L b$. plantarum in sodium alginate via extrusion technology. Results showed that encapsulation enhanced viability of both isolates compared to non-encapsulated ones to the tested harsh conditions; however, encapsulation was more efficient with $L b$. casei compared to Lb. plantarum.

Acknowledgments: Authors acknowledge the Ministry of Higher Education and Scientific Research of Algeria for financial support and acknowledge too the University of Naples Federico II, Italy for its research collaboration.

\section{REFERENCES}

Amine, K. M., Champagne, C. P., Salmieri, S., Britten, M., St-Gelais, D., Fustier, P., \& Lacroix, M. (2014). Effect of palmitoylated alginate microencapsulation on viability of Bifidobacterium longum during freeze-drying. Food Science and Technology, 56 (1), 111-117. http://dx.doi.org//10.1016/j.lwt.2013.11.003

Anal, A. K ., \& Singh, H. (2007). Recent advances in microencapsulation of probiotics for industrial applications and targeted delivery. Trends Food Science \& Technology, 18(5), 240-251. http://dx.doi.org/10.1016/j.tifs.2007.01.004

Bintsis, T. (2018). Lactic acid bacteria: their applications in foods. Journal of $\begin{array}{lllll}\text { Bacteriology and } & \text { Mycology, } & 6 & \text { (2), } & 89-94\end{array}$ http://dx.doi.org/10.15406/jbmoa.2018.06.00182

Bosnea, L. A., Moschakis, T., \& Biliaderis, C. G. (2014). Complex coacervation as a novel microencapsulation technique to improve viability of probiotics under different stresses. Food Bioprocess Technology, 7 (10), 2767-2781. http://dx.doi.org/10.1007/s11947-014-1317-7

Brinques, G. B., \& Ayub, M. A. Z. (2011). Effect of microencapsulation on survival of Lactobacillus plantarum in simulated gastrointestinal conditions, refrigeration, and yogurt. Journal of Food Engineering, 103 (2), 123-128. http://dx.doi.org/10.1016/j.jfoodeng.2010.10.006

Bron, P. A., Baarlen, P. V., \& Kleerebezem, M. (2012). Emerging molecular insights into the interaction between probiotics and the host intestinal mucosa. Nature Reviews. Microbiology, $\quad 10, \quad 66-78$ http://dx.doi.org/10.1038/nrmicro2690

Chávarri, M., Marañón, I., Ares, R., Ibáñez, F.C., Marzo, F., \& Villarán, M.D.C. (2010). Microencapsulation of a probiotic and prebiotic in alginate-chitosan capsules improves survival in simulated gastro-intestinal conditions. International Journal of Food Microbiology, 142 (1-2), 185-189. http://dx.doi.org/10.1016/j.ijfoodmicro.2010.06.022

Chen, H.Y., Li, X.Y., Liu, B. J., \& Meng, X.H. (2017). Microencapsulation of Lactobacillus bulgaricus and survival assays under simulated gastrointestinal conditions. Journal of Functional Foods, 29, 248-255. http://dx.doi.org/10.1016/j.jff.2016.12.015

Cruz, R. G., Pereira, S.G.F., Araújo, E.A., \& Dores, M.T. (2015).Viability of Lactobacillus acidophilus immobilized in calcium alginate spheres and submitted to different conditions of stress. Nutrition and Food Technology, 1, 1-6. http://dx.doi.org/10.16966/2470-6086.101

Damodharan, K., Palaniyandi, S. A., Yang, S. H., \& Suh, J. W. (2017). Coencapsulation of Lactic Acid Bacteria and prebiotic with alginate-fenugreek gum- locust bean gum matrix: Viability of encapsulated bacteria under simulated gastrointestinal conditions and during storage time. Biotechnology and Bioprocess Engineering, 22, 265-271. http://dx.doi.org/10.1007/s12257-0170096-1

De Prisco, A., Maresca, D., Ongeng. D., \& Mauriello, G. (2015) Microencapsulation by vibrating technology of the probiotic strain Lactobacillus reuteri DSM 17938 to enhance its survival in foods and in gastrointestinal environment, LWT - Food Science and Technology, 61(2), 452-462. https://doi.org/10.1016/j.1wt.2014.12.011

Dimitrellou, D., Kandylis, P., Petrovic, T., Dimitrijevic-Brankovic, S., Levic, S., Nedovic, V., \& Kourkoutas, Y. ('b 06). Survival of spray dried microencapsulated Lactobacillus casei ATCC 393 in simulated gastrointestinal conditions and fermented milk. Food Science and Technology ,71, 169-174 http://dx.doi.org/10.1016/j.1wt.2016.03.007

Dong, Q.Y., Chen, M.Y., Xin, Y., Qin, X.Y., Cheng, Z., Shi, L.E., et al. (2013) Alginate based and protein-based materials for probiotics encapsulation: A review. International Journal of Food Science and Technology, 48 (7), 13391351. http://dx.doi.org/10.1111/ijfs.12078

Eratte, D., McKnight, S., Gengenbach, T. R., Dowling, K., Barrow, C. J., \& Adhikari, B. P. (2015). Co-encapsulation and characterisation of omega-3 fatty acids and probiotic bacteria in whey protein isolate-gum Arabic complex coacervates. Journal of Functional Foods, 19, 882-892. http://dx.doi.org/10.1016/j.jff.2015.01.037

FAO/WHO. (2001). Food and Agriculture Organization of the United Nations/World Health Organization. Report on joint FAO/WHO expert consultation on evaluation of health and nutritional properties of probiotics in food including powder milk with live lactic acid bacteria <http://www.who.int/foodsafety/publications/

fs_management/en/probiotics.pdf $>$.

FAO/WHO. (2002). Guidelines for the Evaluation of Probiotics in Food. London, Ontario, Canada.

Gbassi, G. K., Vandamme, T., Ennahar, S., \& Marchioni, E. (2009). Microencapsulation of L. plantarum spp in an alginate matrix coated with whey proteins. International Journal of Food Microbiology, 129 (1), 103-105. http://dx.doi.org/10.1016/j.ijfoodmicro.2008.11.012

Gomes, A. M. P., Teixeira, M.G. M., \& Malcata, F. X. (1998).Viability of Bifidobacterium lactis and Lactobacillus acidophilus in milk: sodium chloride concentration and storage temperature. Journal of Food Processing Preservation, 22, 221-240. http://dx.doi.org/10.1111/j.1745-4549.1998.tb00347.x

Havennar, R., \& Huisint't Veld, M. J. H. (1992). Probiotics; a general review' in the Lactic Acid Bacteria in health and disease. In: Wood, B., Ed. Elsevier, Applied Science, 151- 170. http://dx.doi.org/10.1007/978-1-4615-3522-5_6

Heidebach, T., Först, P., \& Kulozik, U. (2009). Microencapsulation of probiotic cells by means of rennet-gelation of milk proteins. Food Hydrocolloids, 23(7), 1670-1677. http://dx.doi.org/10.1016/i.foodhyd.2009.01.006

Holzapfel, W. H., \& Schillinger, U. (2002). Introduction to pre and probiotics. Food Research International, 35, 109-116. http://dx.doi.org/10.1016/S0963 9969(01)00171-5

Jorgensen, F., Nybroe, O., \& Knochel, S. (1994). Effects of starvation and osmotic stress on viability and heat resistance of Pseudomonas fluorescens AH9. Journal of Applied Microbiology, $77 \quad$ (3), $\quad 340-347$ http://dx.doi.org/10.1111/j.1365-2672.1994.tb03083.x

Klinkenberg, G., Lystad, K.Q., Levine, D.W. \& Dyrset, N. (2001). Cell release from alginate immobilized Lactococcus lactis ssp. Lactis in chitosan and alginate coated beads. Journal of Dairy Science, 84 (5), 1118-1127. http://dx.doi.org/10.3168/jds.S0022-0302(01)74572-9

Krasaekoopt, W., Bhandari, B., \& Deeth, H. (2003). Evaluation of encapsulation techniques of probiotics for yogurt: a review. International Dairy Journal, 13 (1) 3-13. http://dx.doi.org/10.1016/S0958-6946(02)00155-3

Krasaekoopt, W., Bhandari, B., \& Deeth, H. (2006). Survival of probiotics encapsulated in chitosan-coated alginate beads in yogurt form UHT- and conventionally-treated milks during storage. Food Science and Technology, 39 (2), 177-183. http://dx.doi.org/10.1016/j.1wt.2004.12.006

Li, X.Y., Chen, X.G., Sun, Z.W., Park, H.J., \& Cha, D.S. (2011). Preparation of alginate/ chitosan/carboxymethyl chitosan complex microcapsules and application in Lactobacillus casei ATCC 393. Carbohydrate Polymers, 83 (4), 1479-1485. http://dx.doi.org/10.1016/j.carbpol.2010.09.053

Malmo, C., La Storia, A., \& Mauriello, G. (2013). Microencapsulation of Lactobacillus reuteri DSM 17938 cells coated in alginate beads with chitosan by spray drying to use as a probiotic cell in a chocolate soufflé. Food and Bioprocess Technology,6 (3), 795-805. http://dx.doi.org/10.1007/s11947-011 $\underline{0755-8}$

Mandal, S., Puniya, A. K., \& Singh, K., (2006). Effect of alginate concentrations on survival of microencapsulated L. casei NCDC-298. International Dairy Journal 16 (10), 1190-1195. http://dx.doi.org/10.1016/j.idairyj.2005.10.005

Michida, H., Tamalampudi, S., Pandiella, S., Webb, C., Fukuda, H., \& Kondo, A. (2006). Effect of cereal extracts and cereal fiber on viability of L. plantarum under gastrointestinal tract conditions. Biochemical Engineering Journal, 28 (1), 73-78. http://dx.doi.org/10.1016/j.bej.2005.09.004 
Mokarram, R. R., Mortazavi, S. A., HabibiNajafi, M. B., \& Shahidi, F. (2009) The influence of multi stage alginate coating on survivability of potential probiotic bacteria in simulated gastric and intestinal juice. Food Research International, $\quad 42 \quad$ (8), 1040-1045 http://dx.doi.org/10.1016/j.foodres.2009.04.023

Nualkaekul, S., Cook, M. T., Khutoryanskiy, V. V., \& Charalampopoulos, D. (2013). Influence of encapsulation and coating materials on the survival of Lactobacillus plantarum and Bifidobacterium longumin fruit juices. Food $\begin{array}{llll}\text { Research } & \text { International, } & 53 & \text { (1), }\end{array}$ http://dx.doi.org/10.1016/i.foodres.2013.04.019

Rajam, R., Karthik, P., Parthasarathi, S., Joseph, G. S., \& Anandharamakrishnan, C. (2012). Effect of whey protein-alginate wall systems on survival of microencapsulated Lactobacillus plantarum in simulated gastrointestinal conditions. Journal of Functional Foods, 4 (4), 891-898 http://dx.doi.org/10.1016/j.jff.2012.06.006

Schillinger, U., \& Lucke, F. K. (1987). Identification of lactobacilli from meat and meat products. Food Microbiology, 4 (3), 199-208 https://doi.org/10.1016/0740-0020(87)90002-5

Sheehan, V. M., Ross, P., \& Fitzgerald, G. F. (2007). Assessing the acid tolerance and the technological robustness of probiotic cultures for fortification in fruit juices. Innovative Food Science and Emerging Technologies, 8 (2), 279 284. http://dx.doi.org/10.1016/j.ifset.2007.01.007

Sheu, T.Y., Marshall, R.T ., \& Heymann H. (1993). Improving survival of culture bacteria in frozen desserts by microentrapment. Journal of Dairy Science. 76 (7), 1902-1907. http://dx.doi.org/10.3168/jds.S0022-0302(93)77523-

Sidira, M., Galanis, A., Ypsilantis, P., Karapetsas, A., Progaki, Z., Simopoulos, C., et al. (2010). Effect of probiotic-fermented milk administration on gastrointestinal survival of Lactobacillus casei ATCC 393 and modulation of intestinal microbial flora. Journal of Molecular Microbiology and Biotechnology, 19, 224-230. http://dx.doi.org/10.1159/000321115

Stiles, M. E., \& Holzapfel W. H. (1997). Lactic acid bacteria of foods and their current taxonomy. International Journal of Food Science and Technology, 36 (1), 1-29. https://doi.org/10.1016/S0168-1605(96)01233-0

Sultana, K., Godward, G., Reynolds, N., Arumugaswamy, R., Peiris, P., \& Kailasapathy, K. (2000). Encapsulation of probiotic bacteria with alginate-starch and evaluation of survival in simulated gastrointestinal conditions and in yoghurt. International Journal of Food Microbiology, 62 (1-2), 47-55. http://dx.doi.org/10.1016/S0168-1605(00)00380-9

Vasiljevic, T., \& Shah, N. P. (2008). Probiotics -From Metchnikoff to bioactives. $\begin{array}{llll}\text { International Dairy } & \text { Journal, 714-728. }\end{array}$ http://dx.doi.org/10.1016/j.idairyj.2008.03.004

Vinderola, C. G., Costa, G. A., Regenhardt, S., \& Reinheimer, J. A. (2002). Influence of compounds associated with fermented dairy products on the growth of lactic acid starter and probiotic bacteria. International Dairy Journal, 12 (7), 579-589. http://dx.doi.org/10.1016/S0958-6946(02)00046-8

Vizoso Pinto, M.G., Franz, C. M. A. P., Schillinger, U., \& Holzapfel, W.H (2006). Lactobacillus spp. with in vitro probiotic properties from human faeces and traditional fermented products. International Journal of Food Microbiology, 109 (3), 205-214. http://dx.doi.org/10.1016/i.ijfoodmicro.2006.01.029

Vrese, M., \& Schrezenmeir, J. (2008). Probiotics, prebiotics, and synbiotics. Advances in Biochemical Engineering/Biotechnology, 111, 1-66. http://dx.doi.org/10.1007/10.2008.097

Wang, J., Korber, D. R., Low, N. H., \& Nickerson, M. T. (2014). Entrapment survival and release of Bifidobacterium adolescentis within chickpea protein based microcapsules. Food Research International, 55, 20-27. http://dx.doi.org/10.1016/j.foodres.2013.09.018

Xanthopoulus, V., Hatzikamari, M., Adamidis, T., Tsakalidou, E., Tzanetakis, N ., \& Litopulou-Tzanetakis, E. (2000). Heterogeneity of Lactobacillus plantarum isolates from feta cheese throughout ripening. Journal of Applied Microbiolgy, 88 (6), 1056-1064. https://doi.org/10.1046/i.1365-2672.2000.01056.x

Xu, M., Gagne-Bourque, F., Dumont, M.J., \& Jaba, S. (2016). Encapsulation of Lactobacillus casei ATCC 393 cells and evaluation of their survival after freezedrying, storage and under gastrointestinal conditions. Journal of Food Engineering, 168, 52-59. http://dx.doi.org/10.1016/j.jfoodeng.2015.07.021 